\title{
Differential gene expression, induced by salicylic acid and Fusarium oxysporum f. sp. lycopersici infection, in tomato
}

\author{
Daniel Oliveira Jordão do Amaral(1), Marleide Magalhães de Andrade Lima ${ }^{(2)}$, \\ Luciane Vilela Resende ${ }^{(1)}$ and Márcia Vanusa da Silva(3)
}

\begin{abstract}
(1)Universidade Federal Rural de Pernambuco, Laboratório de Biotecnologia Vegetal, CEP 52171-900 Recife, PE, Brazil. E-mail: danieljornal@yahoo.com.br, lucianevilela@uol.com.br (2)Embrapa Algodão, Núcleo de Biotecnologia, Caixa Postal 174, CEP 58107-720 Campina Grande, PB, Brazil. E-mail: marleide@cnpa.embrapa.br (3)Universidade Federal de Pernambuco, Centro de Ciências Biológicas, Departamento de Bioquímica, CEP 50670-901 Recife, PE, Brazil. E-mail: marcia.vanusa@ufpe.br
\end{abstract}

\begin{abstract}
The objective of this work was to determine the transcript profile of tomato plants (Lycopersicon esculentum Mill.), during Fusarium oxysporum $\mathrm{f}$. sp. lycopersici infection and after foliar application of salicylic acid. The suppression subtractive hybridization ( $\mathrm{SSH}$ ) technique was used to generate a cDNA library enriched for transcripts differentially expressed. A total of 307 clones was identified in two subtractive libraries, which allowed the isolation of several defense-related genes that play roles in different mechanisms of plant resistance to phytopathogens. Genes with unknown roles were also isolated from the two libraries, which indicates the possibility of identifying new genes not yet reported in studies of stress/defense response. The SSH technique is effective for identification of resistance genes activated by salicylic acid and $F$. oxysporum f. sp. lycopersici infection. Not only the application of this technique enables a cost effective isolation of differentially expressed sequences, but also it allows the identification of novel sequences in tomato from a relative small number of sequences.
\end{abstract}

Index terms: Lycopersicon esculentum, cDNA libraries, complementary DNA, gene expression, salicylic acids, suppression subtractive hybridization.

\section{Expressão diferencial de genes induzida por ácido salicílico e por Fusarium oxysporum f. sp. lycopersici, em tomateiro}

\begin{abstract}
Resumo - O objetivo deste trabalho foi determinar o perfil de transcritos em plantas de tomate (Lycopersicon esculentum Mill.), durante a infecção com Fusarium oxysporum f. sp. lycopersici e após a aplicação foliar de ácido salicílico. A técnica de hibridização subtrativa por supressão (SSH) foi utilizada para gerar uma biblioteca de cDNA enriquecida por transcritos diferencialmente expressos. Foram identificados 307 clones, em duas bibliotecas subtrativas, que permitiram o isolamento de diversos genes de defesa com função em diferentes processos relacionados à resistência vegetal contra patógenos. Também foram isolados, nas duas bibliotecas, genes com função desconhecida, o que indica a possibilidade de identificação de novos genes que ainda não tenham sido relatados em estudos anteriores de resposta a estresses e defesa, em plantas. A técnica SSH é eficiente em identificar genes de resistência, ativados pelo ácido salicílico e pela infecção com Fusarium oxysporum f. sp. lycopersici. A aplicação dessa técnica não apenas possibilita isolar seqüências diferencialmente expressas, a baixo custo, como também permite a identificação de novas seqüências, em tomate, a partir de um número relativamente pequeno de seqüências.
\end{abstract}

Termos para indexação: Lycopersicon esculentum, bibliotecas de cDNA, DNA complementar, expressão gênica, ácido salicílico, hibridização subtrativa por supressão.

\section{Introduction}

Fusarium wilt, caused by Fusarium oxysporum f. sp. lycopersici, is one of the main diseases of tomato (Lycopersicon esculentum Mill.). Three physiological races (1,2 and 3) have been identified. Resistant cultivars are the best wilt control strategy, since the pathogen remains in the soil for some decades and chemical control is ineffective (Reis et al., 2004).
Plant resistance to diseases is associated with a number of defense responses, activated by the host after contact with the pathogens. Resistance is often expressed as a hypersensitive reaction, which results in localized cell death at the pathogen penetration site. Other resistance responses may include structural alterations, accumulation of reactive oxygen species, synthesis of secondary metabolites and production 
of a wide variety of defense molecules, such as antimicrobial proteins (Park et al., 2003; Shah, 2003; Ros et al., 2004). Defense responses are induced in pathogenesis-related situations, observed after the application of chemical substances, which simulate the effect of pathogen infection (e.g. salicylic acid - SA), which triggers the production of PR proteins (pathogenesis related proteins) (Van Loon, 1985).

The identification of host genes, involved in defense responses, is important to understand plant resistance mechanisms against phytopathogens (Thatcher et al., 2005; Desender et al., 2007). Suppression subtractive hybridization ( $\mathrm{SSH}$ ) is a promising technique for the isolation of genes expressed in plants subjected to biotic and abiotic stress, because it increases the relative abundance of some cDNA species (Diatchenko et al., 1996; Soares, 1997). The advantages of this technique include the detection of low-abundant and differentially expressed transcripts through suppression of the abundant ones, and the capacity of isolating genes with no previous knowledge of their sequence or identity (Diatchenko et al., 1999; Moody, 2001).

The objective of this work was to determine the transcript profile in tomato plants (Lycopersicon esculentum Mill.), during Fusarium oxysporum f. sp. lycopersici infection, and after the foliar application of the signaling molecules of salicylic acid.

\section{Materials and Methods}

Tomato seeds of the cultivar BHR, resistant to F. oxysporum f. sp. lycopersici, were germinated aseptically on MS culture medium $(0.8 \% \mathrm{w} / \mathrm{v}$ agar $)$, with the $\mathrm{pH}$ adjusted to $5.8 \pm 0.2$, photoperiod of 16 hours of light and 8 hours of dark, and temperature at $25 \pm 2^{\circ} \mathrm{C}$. Plants were kept in these conditions for three weeks after germination.

Three-week old plants were, then, sprayed with $5 \mathrm{mM}$ sodium salicylate (Sigma, USA) dissolved in autoclaved distilled water. Untreated control plants were sprayed with autoclaved distilled water. Leaves of ten plants were harvested 24 hours after the treatment, mixed and used for total RNA extraction. Mahalingam et al. (2003) identified differentially expressed genes in Arabidopsis using leaf tissue 24 hours after exposure to salicylic acid to build their SSH library. However, gene expression alterations, in response to soil pathogens, are usually studied in root tissues, after a pathogen germination and penetration period (Benhamou et al., 1990; Divon et al., 2005; Olivain et al., 2006). In order to capture a wide spectrum of differentially expressed genes, leaf and root tissues were collected after the treatment and pooled before RNA extraction.

For inoculation, Fusarium oxysporum f. sp. lycopersici (race 2) conidiospores were collected from potato dextrose agar (PDA) plates by flooding a 2-week old culture with a solution of $0.01 \%(\mathrm{v} / \mathrm{v})$ Tween 20 and rubbing the surface. The spore suspension was filtered through glass wool to remove mycelial fragments. The spore concentration was determined using a hemocytometer. The plants were infected through the root cut method (Santos, 1997) for $10 \mathrm{~min}$. Control plants were treated with autoclaved distilled water. After inoculation, the plants were transferred to new tubes containing MS liquid medium, and the roots were harvested 72 hours after, mixed and used for total RNA extraction.

For total RNA extraction, the leaves from SA treated plants and roots from Fusarium infected plants were used with Trizol $\left(100 \mathrm{mg} \mathrm{mL}^{-1}\right)$. RNA yield was $50 \mu \mathrm{g}$ per $100 \mathrm{mg}$ of plant tissue. Complementary DNA was obtained through SMART PCR cDNA Synthesis Kit.

Suppression subtractive hybridization was performed with the PCR-select cDNA subtraction kit. Treated and control samples were processed simultaneously to reduce false positives. Complementary DNA, prepared from the treated samples, was used as "tester", and that from the control sample as "driver", for the forward subtraction carried out to isolate fragments corresponding to genes whose expression level was increased following the treatments. The PCR-based enrichment of differentially expressed sequences depends on the number of tester molecules with adaptors ligated to their ends. When the fraction of tester cDNA with the adaptors was less than $25 \%$, the ligations were repeated. It was designed a plant-specific translation elongation factor $1 \alpha(\mathrm{EF}-1 \alpha)$ primer to test the ligation efficiency, as recommended by the manufacturer.

A EF-1 $\alpha$ gene fragment of approximately 300 bp was amplified with: EF-1 $\alpha$ R: 5'GACAATCAAGCACTGGAGCA3' and EF-1 $\alpha$ F: 5'GATGCTACCACCCCCAAGTA3', using the adaptor-ligated cDNA as template. Samples from the EF-1 $\alpha$ gene fragment amplifications, using the subtracted and unsubtracted cDNA pools, were analyzed after 15, 20, 25 and 30 cycles of PCR 
(Pokalsky et al., 1989). Primers used to amplify regions without an $R s a \mathrm{I}$ site were designed for one stress-induced gene, the pathogen-inducible PR4 gene: Chi3 F: 5'GTTTCCAGGTTTTGGTACTGCTGGT3' and Chi3 R: 5'CCACAATACCTCCTGTAAAATCCA A3'; these were used to test the subtraction efficiency of the corresponding libraries before cloning.

Cloned PCR products, in the vector T/A PCR2.1 TOPO were, then, transformed with DH5 $\alpha$ competent cells to produce all the subtracted libraries (forward $\mathrm{SSH}$ ), according to manufacturer's instructions. Cell colonies were transferred to LB liquid medium containing $100 \mu \mathrm{g} \mathrm{mL}^{-1}$ kanamycin, and were cultured for 16 hours. Plasmid DNA was extracted by the alkaline lysis mini-preparation method (Sambrook \& Russell, 2001). Recombinant plasmids were identified, by restriction analysis, and subjected to DNA sequencing.

The efficiency of subtraction was evaluated by PCR amplification of one of several differentially expressed genes, and of a housekeeping gene - the one for translation elongation factor $1 \alpha(\mathrm{EF}-1 \alpha)$. To test enrichment for differentially expressed genes, the PR4 gene (Chi3) was amplified for the biotic stress.

Nucleotide sequences of each insert were determined in an automatic DNA sequencer (ABI PRISM 377), with the Big Dye Terminator kit. Conventional M13-forward and M13-reverse primers were used to determine DNA sequences. Obtained sequences were compared with the ones in the databanks of: the National Center for Biotechnology Information, NCBI (http://www.ncbi. nlm.nih.gov/blast), using the program BlastX (Altschul et al., 1997); the Institute for Genomic Research, TIGR (http://compbio.dfci.harvard.edu/tgi/cgi-bin/tgi/Blast/ index.cgi); and the DNA Data Bank of Japan, DDBJ (http://www.ddbj.nig.ac.jp/search/blast). Sequences were aligned with the software ClustalW (http://www. ebi.ac.uk) (Thompson et al., 1994).

\section{Results and Discussion}

Two cDNA libraries were constructed through SSH technique, one with genes induced by salicylic acid (SA) e another with genes induced by $F$. oxysporum f. sp. lycopersici (FO) infection, as shown in Table 1.

If subtraction is efficient, transcripts of housekeeping genes should be reduced, while those of differentially expressed genes should be substantially enriched in the population of cDNA fragments used for library construction. Figure 1 shows that the EF-1 $\alpha$ fragment is barely detectable, even after 30 cycles of amplification in the subtracted sample, while it is clearly detectable in the unsubtracted sample after 20 cycles. To test enrichment for differentially expressed genes, the PR4 gene (Chi3), for the biotic stress, was tested and showed strong amplification in the subtracted samples, after 20 cycles of PCR whereas, in the unsubtracted samples, the PCR product was seen only after 5 additional cycles (Figure 1). Subtraction was efficient, because the expression of EF-1 $\alpha$ transcripts was reduced, while the differentially expressed PR4 gene was substantially enriched in the cDNA fragment population used in the SSH library construction. On the basis of the number of PCR cycles required for equal amplification of the corresponding PCR products, from the subtracted and unsubtracted cDNA samples, it was estimated that the subtracted libraries were 64-fold enriched for differentially expressed genes. One of the main advantages of SSH is that it normalizes the cDNA abundance, so that cDNAs encoded by genes that are expressed infrequently, but nonetheless differentially, can be identified readily (Diatchenko et al., 1996; Kürkcüoglu et al., 2006).

After SSH, 307 cDNA clones were obtained, being 143 clones from the SA library and 164 from the FO library (Table 1). Inserted length ranged from 300 to $1,100 \mathrm{bp}$, in the two libraries. Clone similarity was considered at E-values lower than $10^{-5}$ in the different data banks analyzed, being, thus, significant

Table 1. Treatments used to obtain suppression subtractive hybridization (SSH) cDNA libraries.

\begin{tabular}{|c|c|c|c|c|c|}
\hline Treatment & Control & Time (hours) & Library identification & Total clones & Number of clones per category \\
\hline $5 \mathrm{mM}$ salicylic acid & $\mathrm{H}_{2} \mathrm{O}$ & 24 & Tomato - SA & 143 & $\begin{array}{l}46 \text { unknown roles } \\
34 \text { defense/stress related } \\
24 \text { general metabolism } \\
39 \text { no similarity }\end{array}$ \\
\hline $\begin{array}{l}\text { F. oxysporum f.sp. } \\
\text { lycopersici }\left(10^{7} \mathrm{~mL}^{-1}\right)\end{array}$ & $\mathrm{H}_{2} \mathrm{O}$ & 72 & Tomato - FO & 164 & $\begin{array}{l}49 \text { unknown roles } \\
42 \text { defense/stress related } \\
44 \text { general metabolism } \\
29 \text { no similarity }\end{array}$ \\
\hline
\end{tabular}


(Fernández et al., 2003). In the SA library, 39 clones encoded proteins with no similarity, 46 were similar to putative proteins with unknown roles, 34 clones represented genes involved in defense mechanisms and 24 clones were associated to cell maintenance and plant development. From the 164 clones identified in the FO library, 29 showed no similarity with data bank sequences, 49 were analogous to hypothetical proteins, 42 corresponded to genes involved in defense mechanisms, and 44 were related to cell maintenance and plant development. Results are summarized in Table 1.

The identification of host genes involved in defense responses is important to unravel mechanisms of plant resistance against phytopathogens. Suppression subtractive hybridization combines suppression PCR with subtraction and normalization steps in a single reaction, increasing, therefore, the possibility of identifying low expressed genes (Diatchenko et al.,

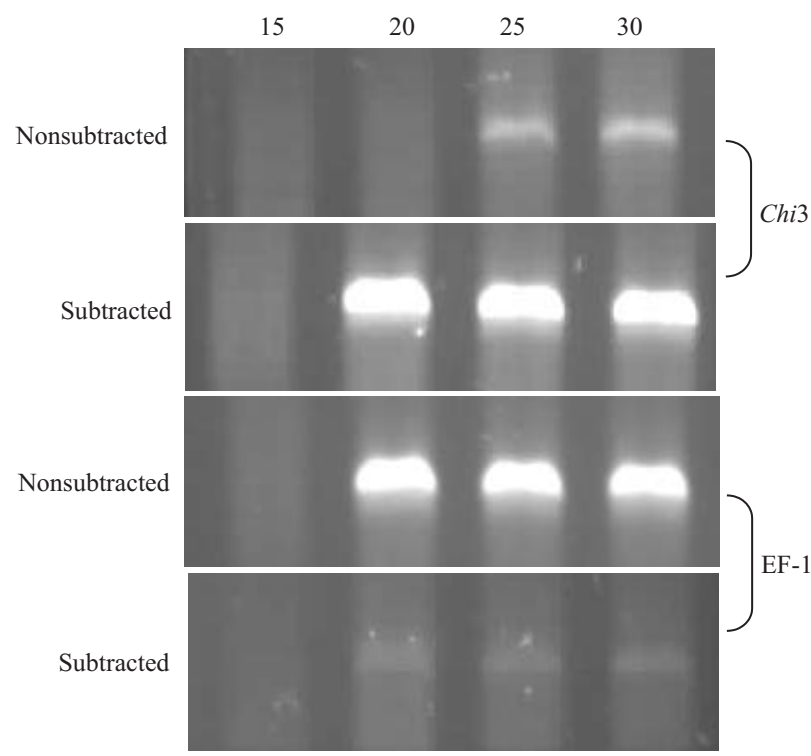

Figure 1. Subtraction efficiency analysis using PCR. Tester cDNA was prepared from total RNA from plants infected with $F$. oxysporum f. sp. lycopersici, and driver cDNA was prepared from water treated controls. Subtracted and nonsubtracted cDNA pools were amplified with the primer that amplifies Chi3 induced by pathogen infection or amplifies the gene EF-1 $\alpha$ expressed constitutively. Numbers above are aliquots taken after 15, 20, 25 and 30 PCR cycles. Amplified products were analyzed in $1.5 \%$ agarose gel.
1999; Moody, 2001). Genes with unknown roles were identified in SA and FO libraries, which indicates the possibility of identifying new genes that have not yet been reported in previous studies of stress/defense response. Similar results were observed in SSH libraries from Arabidopsis, potato and tomato, in biotic stress conditions (Mahalingam et al., 2003; Ros et al., 2004; Ouyang et al., 2007).

Figures 2 and 3 show that a higher number of genes involved in defense mechanisms were found in the FO library. The group of unknown genes represented $32 \%$ of the SA library and $29 \%$ of the FO library. One of the most interesting characteristics of SSH was achieved with the description of relatively rare cDNA fragments, obtained by simultaneous normalization and subtraction steps. The normalization step equalizes the abundance of mRNA within the target population, and the subtraction step excludes sequences that are common to the two populations being compared. However, the SSH methodology allows the detection of low copy transcripts, and it allows the identification of unknown genes (Diatchenko et al., 1996, 1999; Moody, 2001).

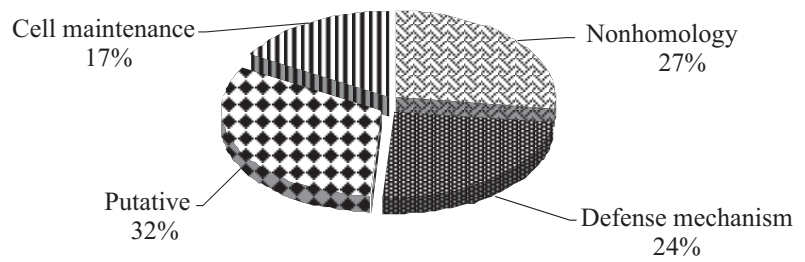

Figure 2. Genes activated in the tomato cultivar BHR treated with salicylic acid (SA). Genes were isolated by suppression subtractive hybridization, from tomato mRNAs, 24 hours after SA treatment.

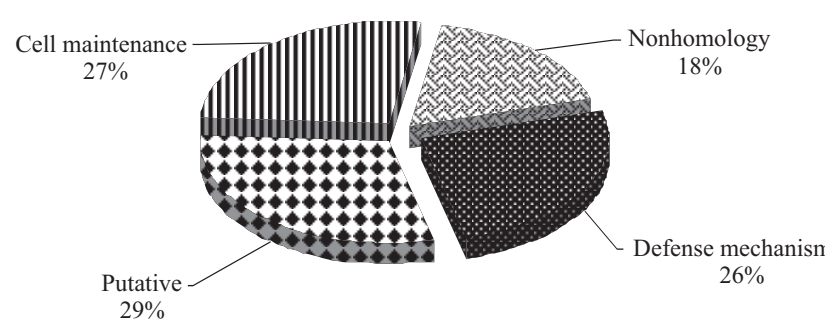

Figure 3. Genes expressed in the tomato cultivar BHR after $F$. oxysporum f. sp. lycopersici inoculation. Genes were isolated by suppression subtractive hybridization from tomato mRNAs 72 hours after the inoculation of 107 spores $\mathrm{mL}^{-1}$. 
The amount of genes involved in each process related to plant resistance, activated in both $\mathrm{SSH}$ libraries, are shown in Figure 4. A higher number of genes related to signal perception and transduction, encoding antimicrobial proteins related to oxidative stress and cell death, was observed in the FO library. However, the number of genes related to the synthesis and transport of secondary metabolism compounds and controlled protein breakdown was higher in the SA

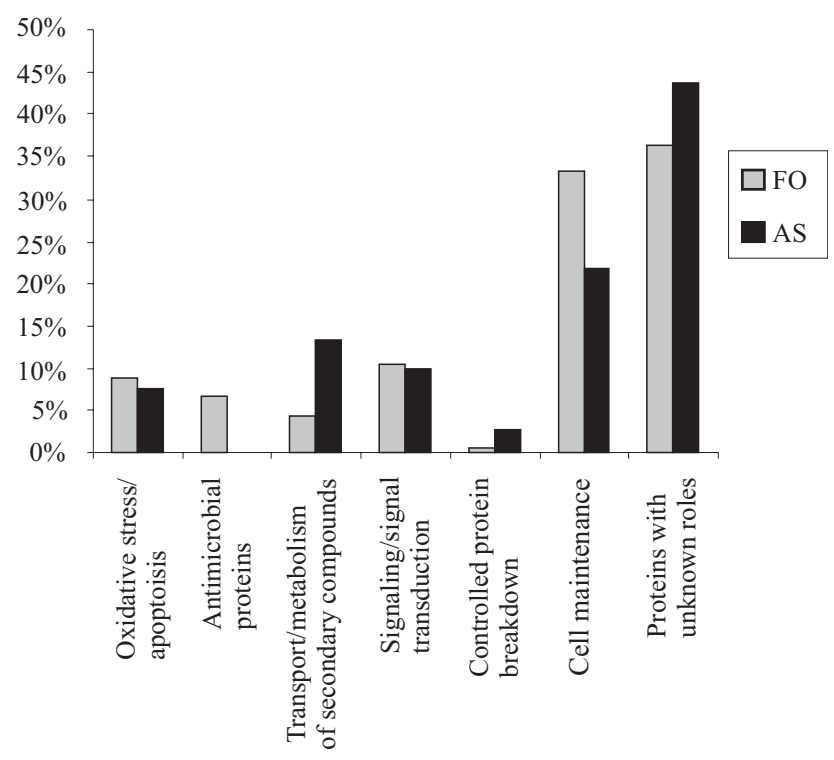

Figure 4. Comparison of Expressed Sequences Tags (ESTs) classified by the predicted role between two tomato cDNA libraries, induced by salicylic acid (SA) and F. oxysporum f. sp. lycopersici (FO). library. Figure 4 also shows a higher amount of genes related to cell maintenance in the FO library. Genes with cell maintenance and plant development roles were identified in both libraries. Results indicate that there is activation of primary metabolism pathways, together with the induction of several signaling pathways, for the expression of defense-related genes (HammondKosack \& Jones, 1996; Birch et al., 1999; Mahalingam et al., 2003).

Plant genes with known roles, involved in biotic and abiotic stress response and associated to cell maintenance and plant development, were identified in both SA and FO libraries. Some of these genes, as those encoding phenylalanine ammonia lyase, chitinase, late embryogenesis abundant protein, bZip transcription factor, zinc finger domain protein, and I-2 disease resistance protein with leucine-rich repeat, are related to defense mechanisms, while genes encoding cytochrome, ubiquitin, photosystem II apoprotein and ribosomal $60 \mathrm{~S}$ protein are related to cell metabolism (Tables 2 and 3).

A gene that is exclusive to the plant-pathogen interaction type was identified in the FO library. It is a cDNA clone which showed highly significant similarity to an Oryza sativa gene, encoding a protein from the hypersensitive induced reaction (HIR) family. Members of this family are related to hypersensitivity reaction, involving cell death and resistance to pathogens (Nadimpalli et al., 2000). This gene was also induced in tomato plants with constitutive expression of the resistance gene Pto (35S::Pto) (Xiao et al., 2001).

Table 2. Identification of salicylic acid-induced genes in tomato (Lycopersicon esculentum) with similarity to known genes from other plant species.

\begin{tabular}{|c|c|c|}
\hline Clone $^{(1)}$ & Gene description (acess no.) $)^{(2)}$ & E-value ${ }^{(3)}$ \\
\hline AS - 010 & Acil - CoA synthase [Capsicum annuum] (AAL29212) & $1.4 \mathrm{e}-53$ \\
\hline AS - 023 & Late embryogenesis abundant protein [Nicotiana tabacum] (TC174494) & $8.5 e-62$ \\
\hline AS - 044 & Ubiquitin [Solanum tuberosum] (TC170024) & $9.9 \mathrm{e}-55$ \\
\hline AS - 053 & Cytochrome b6 [Arabidopsis thaliana] (TC190079) & $1.4 \mathrm{e}-21$ \\
\hline AS - 061 & Disease resistance protein PR-10 [Capsicum annuum] (Q2VT55) & $9.1 \mathrm{e}-49$ \\
\hline AS - 067 & Chalcone synthase $2[$ Camellia sinensis $]$ (P48387) & $2.0 \mathrm{e}-91$ \\
\hline AS - 072 & Manganese superoxide dismutase [Lycopersicon esculentum] (TC18915) & $8.3 e-34$ \\
\hline AS - 080 & Zinc finger domain protein $[$ Arabidopsis thaliana $]$ (TC172334) & $4.7 \mathrm{e}-43$ \\
\hline AS - 095 & $60 \mathrm{~S}$ ribosomal protein $[$ Lycopersicon esculentum] (TC172591) & $4.5 e-54$ \\
\hline AS - 112 & Caspase 1 [Lycopersicon esculentum] (TC188871) & $1.8 \mathrm{e}-66$ \\
\hline AS - 115 & bZIP family transcription factor [Solanum tuberosum] (TC180148) & $6.7 \mathrm{e}-86$ \\
\hline AS -127 & Photosystem II apoprotein (47 kDa) [Arabidopsis thaliana] (TC182559) & $1.9 \mathrm{e}-27$ \\
\hline AS - 132 & BHLH-like transcription factor [Arabidopsis thaliana] (Q8S3E0) & $6.4 \mathrm{e}-46$ \\
\hline AS - 142 & Phenylalanine ammonia lyase [Lycopersicon esculentum] (TC172772) & $1.2 \mathrm{e}-79$ \\
\hline AS - 143 & CIPK-like protein kinase [Arabidopsis thaliana] (NP566580) & $9.0 \mathrm{e}-30$ \\
\hline
\end{tabular}

${ }^{(1)}$ Genes isolated by suppression subtractive hybridization, from salicylic acid treated tomato mRNAs. ${ }^{(2)}$ Gene roles were identified with homologue sequences from NCBI, TIRG and DDBJ, using the program BlastX. ${ }^{(3)} \mathrm{E}$-value was used to indicate the significance of the similarity for each gene. 
Table 3. Identification of tomato (Lycopersicon esculentum) genes induced by F. oxysporum f.sp. lycopersici with similarity to known genes from other plant species.

\begin{tabular}{|c|c|c|}
\hline Clone $^{(1)}$ & Gene description (acess number) ${ }^{(2)}$ & E-value $^{(3)}$ \\
\hline FO - 007 & ABC transporter protein [Oryza sativa] (BAC55994) & $7.4 \mathrm{e}-50$ \\
\hline FO - 023 & Hypersensitivity-induced response protein [Oryza sativa] (AAK54610) & $1.3 e-44$ \\
\hline $\mathrm{FO}-027$ & Phospholipase [Arabidopsis thaliana] (AAL87258) & $2.8 \mathrm{e}-41$ \\
\hline FO - 041 & Chitinase [Solanum lycopersicum] (BAC76900) & 1.e-148 \\
\hline FO - 069 & Cytochrome P450 [Arabidopsis thaliana] (AI776695) & $1.1 \mathrm{e}-31$ \\
\hline FO - 084 & LeMir protein [Lycopersicon esculentum] (TC171566) & $3.6 e-45$ \\
\hline FO - 089 & Phenylalanine ammonia lyase [Lycopersicon esculentum] (TC172772) & $3.1 \mathrm{e}-78$ \\
\hline FO - 093 & I-2 disease resistance protein with leucine-rich repeat [Oryza sativa] (BAB89710) & $6.0 \mathrm{e}-35$ \\
\hline FO - 098 & Osmotin-like protein [Solanum commersonii] (P50702) & $1.0 \mathrm{e}-32$ \\
\hline FO - 099 & Cysteine proteinase inhibitor [Lycopersicon esculentum] (TC172677) & $1.2 \mathrm{e}-56$ \\
\hline FO - 103 & Xyloglucan-specific fungal endoglucanase inhibitor protein [Lycopersicon esculentum] (TC188664) & $1.4 \mathrm{e}-63$ \\
\hline FO - 115 & Ubiquitin [Arabidopsis thaliana] (Q45W78) & $2.3 e-32$ \\
\hline FO - 130 & Serine/threonine protein kinase [Nicotiana tabacum] (Q1W0X1) & $1.1 \mathrm{e}-25$ \\
\hline FO - 145 & CGI-144-like protein (pathogen-induced) [Lycopersicon esculentum] (CAC81814) & $1.3 e-61$ \\
\hline FO - 152 & Catalase [Gossypium hirsutum] (S10395) & $2.2 \mathrm{e}-55$ \\
\hline FO - 155 & Cysteine proteinase [Ipomea batatas] (AAQ81938) & $3.7 e-19$ \\
\hline
\end{tabular}

${ }^{(1)}$ Genes isolated by suppression subtractive hybridization, from mRNAs of tomato plants infected with F. oxysporum f. sp. lycopersici. ${ }^{(2)}$ Gene roles were identified with homologue sequences from NCBI, TIRG and DDBJ, using the program BlastX. ${ }^{(3)} \mathrm{E}$-value was used to indicate the significance of the similarity for each gene.

The detection of a gene from the HIR family in tomato, which may be involved in the mediation of programmed cell death, was also made by Solomon et al. (1999).

Genes encoding antimicrobial proteins were only detected in the FO library. A chitinase-encoding gene, probably representing an acidic protein, likely belongs to a group of glycosyl hydrolases from family 19. In the interaction between a resistant potato cultivar and Phytophthora infestans, the expression of antimicrobial proteins related to defense mechanisms was observed at the formation of the first haustoria in the plant cell, from 48 to 72 hours after inoculation (Ros et al., 2004).

This is the first report of global gene expression in tomato induced by salicylic acid and $F$. oxysporum $\mathrm{f}$. sp. lycopersici using the SSH technique. It was possible to isolate and identify novel sequences in tomato from a relative small number of analyzed sequences, when compared to major sequencing projects (Birch et al., 1999; Werne et al., 2001; Xiong et al., 2001; Mahalingam et al., 2003; Ros et al., 2004; Ouyang et al., 2007). The present work provides a valuable starting point for further elucidation of the roles played by these genes and gene products in pathogen resistance in tomato.

\section{Conclusions}

1. The technique of suppression subtractive hybridization (SSH) is effective for the identification of resistance genes activated by salicylic acid and Fusarium oxysporum f. sp. lycopersici.

2. Not only does the application of SSH technique enable a cost effective isolation of differentially expressed sequences, but also it allows the identification of novel sequences in tomato from a relative small number of sequences.

\section{References}

ALTSCHUL, S.F.; MADDEN, T.L.; SCHÄFFER, A.A.; ZHANG, J.; ZHANG, Z.; MILLER, W.; LIPMAN, D.J. Gapped BLAST and PSI-BLAST: a new generation of protein database search programs. Nucleic Acids Research, v.25, p.3389-3402, 1997.

BENHAMOU, N.; JOOSTEN, M.H.A.J.; WIT, P.J.G.M. Subcellular localization of chitinase and of its potential substrate in tomato root tissues infected by Fusarium oxysporum f. sp. radicis-lycopersici. Plant Physiology, v.92, p.1108-1120, 1990.

BIRCH, P.R.J.; AVROVA, A.O.; DUNCAN, J.M.; LYON, G.D.; TOTH, R.L. Isolation of potato genes that are induced during an early stage of the hypersensitive response to Phytophthora infestans. Molecular Plant-Microbe Interactions, v.12, p.356-361, 1999.

DESENDER, S.; ANDRIVON, D.; VAL, F. Activation of defence reactions in Solanaceae: where is the specificity? Cellular Microbiology, v.9, p.21-30, 2007. 
DIATCHENKO, L.; LAU, Y.F.; CAMPBELL, A.P.; CHENCHIK, A.; MOQADAM, F.; HUANG, B.; LUKYANOV, S.; LUKYANOV, K.; GURSKAYA, N.; SVERDLOV, E.D.; SIEBERT, P.D. Suppression subtractive hybridization: a method for generating differentially regulated or tissue-specific cDNA probes and libraries. Proceedings of the National Academy of Sciences of the USA, v.93, p.6025-6030, 1996.

DIATCHENKO, L.; LUKYANOV, S.; LAU, Y.F.; SIEBERT, P.D. Suppression subtractive hybridization: a versatile method for identifying differentially expressed genes. Methods in Enzymology, v.303, p.349-380, 1999.

DIVON, H.H.; ROTHAN-DENOYES, B.; DAVYDOV, O.; DI PIETRO, A.; FLUHR, R. Nitrogen-responsive genes are differentially regulated in plants during Fusarium oxysporum f. sp. lycopersici infection. Molecular Plant Pathology, v.6, p.459-470, 2005.

FERNÁNDEZ, P.; PANIEGO, N.; LEW, S.; HOPP, H.E.; HEINZ, R.A. Differential representation of sunflower ESTs in enriched organ-specific cDNA libraries in a small scale sequencing project. BMC Genomics, v.4, p.1-9, 2003.

HAMMOND-KOSACK, K.E.; JONES, J.D.G. Resistance gene-dependent plant defense responses. The Plant Cell, v.8, p.1773-1791, 1996.

KÜRKCÜOGLU， S.; DEGENHARDT， J.; LENSING， J.; AL-MASRI, A.N.; GAU, A.E. Identification of differentially expressed genes in Malus domestica after application of the non-pathogenic bacterium Pseudomonas fluorescens $\mathrm{Bk} 3$ to the phyllosphere. Journal of Experimental Botany, v.22, p.1-9, 2006.

MAHALINGAM, R.; GOMEZ-BUITRAGO, A.M.; ECKARDT, N.; SHAH,N.; GUEVARA-GARCIA,A.;DAY,P.; RAINA, R.; FEDOROFF, N.V. Characterization of the stress/defense transcriptome of Arabidopsis genome biology. Genome biology, v.4, p.R20.1-R20.14, 2003.

MOODY, D.E. Genomics techniques: an overview of methods for the study of gene expression. Journal of Animal Science, v.79, p.E128-E135, 2001.

NADIMPALLI, R.; YALPANI, N.; GURMUKH, S.J.; SIMMONS, C.R. Prohibitins, stomatins, and plant disease response genes compose a protein superfamily that controls cell proliferation, ion channel regulation, and death. Journal of Biological Chemistry, v.275, p.29579-29586, 2000.

OLIVAIN, C.; HUMBERT, C.; NAHALKOVA, J.; FATEHI, J.; L'HARIDON, F.; ALABOUVETTE, C. Colonization of tomato root by pathogenic and nonpathogenic Fusarium oxysporum strains inoculated together and separately into the soil. Applied and environmental microbiology, v.72, p.1523-1531, 2006

OUYANG, B.; YANG, T.; LI, H.; ZHANG, L.; ZHANG, Y.; ZHANG, J.; FEI, Z.; YE, Z. Identification of early salt stress response genes in tomato root by suppression subtractive hybridization and microarray analysis. Journal of Experimental Botany, v.58, p.507-520, 2007.

PARK, Y.S.; MIN, H.J.; RYANG, S.H.; OH, K.J.; CHA, J.S.; KIM, H.Y.; CHO, T.J. Characterization of salicylic acid-induced genes in Chinese cabbage. Plant Cell Reports, v.21, p.1027-1034, 2003.
POKALSKY, A.R.; HIATT, W.R.; RIDGE, N.; RASMUSSEN, R.; HOUCK, C.M.; SHEWMAKER, C.K. Structure and expression of elongation factor $1 \alpha$ in tomato. Nucleic Acids Research, v.17, p.4661-4673, 1989.

REIS, A.; GIORDANO, L.B.; LOPES, C.A.; BOITEUX, L.S. Novel sources of multiple resistance to three races of Fusarium oxysporum f. sp. lycopersici in Lycopersicon germplasm. Crop Breeding and Applied Biotechnology, v.4, p.495-502, 2004.

ROS, B.; TUMMLER, F.; WENZEL, G. Analysis of differentially expressed genes in a susceptible and moderately resistant potato cultivar upon Phytophthora infestans infection. Molecular Plant Pathology, v.5, p.191-201, 2004.

SAMBROOK, J.; RUSSELL, D.W. Molecular cloning: a laboratory manual. 3.ed. New York: Cold Spring Harbor Laboratory Press, 2001. 2100p.

SANTOS, J.R.M. Methodology for screening tomato for Fusarium wilt, Verticillium wilt, gray leaf spot, early blight, and Septoria leaf spot. In: INTERNATIONAL SYMPOSIUM ON TROPICAL TOMATO DISEASES, 1., 1996, Recife. Proceedings. Alexandria: ASHS, 1997. p.164-166.

SHAH, J. The salicylic acid loop in plant defense. Current Opinion in Plant Biology, v.6, p.365-371, 2003.

SOARES, M.B. Identification and cloning of differentially expressed genes. Current Opinion in Biotechnology, v.8, p.542546, 1997.

SOLOMON, M.; BELENGHI, B.; DELLEDONNE, M.; MENACHEM, E.; LEVINE, A. The involvement of cysteine proteases and protease inhibitor genes in the regulation of programmed cell death in plants. Plant Cell, v.11, p.431-443, 1999.

THATCHER, L.F.; ANDERSON, J.P.; SINGH, K.B. Plant defence responses: what have we learnt from Arabidopsis? Functional Plant Biology, v.32, p.1-19, 2005.

THOMPSON, J.D.; HIGGINS, D.G.; GIBSON, T.J. CLUSTAL W: improving the sensitivity of progressive multiple alignment through sequence weighting, position-specific gap penalties and weight matrix choice. Nucleic Acids Research, v.22, p.4673-4680, 1994.

VAN LOON, L.C. Pathogenesis-related proteins. Plant Molecular Biology, v.4, p.111-116, 1985.

WERNE, M.; UEHLEIN, N.; PROKSCH, P.; KALDENHOFF, R. Characterization of two tomato aquaporins and expression during the incompatible interaction of tomato with the plant parasite Cuscuta reflexa. Planta, v.213, p.550-555, 2001.

XIAO, F.; TANG, X.; ZHOU, J.M. Expression of 35S::Pto globally activates defense-related genes in tomato plants. Plant Physiology, v.126, p.1637-1645, 2001.

XIONG, L.; LEE, M.W.; QI, M.; YANG, Y. Identification of defense-related rice genes by suppression subtractive hybridization and differential screening. Molecular Plant-Microbe Interactions, v.14, p.685-692, 2001.

$\overline{\text { Received on March 14, } 2008 \text { and accepted on July 18, } 2008}$ 